\title{
Teaching of Professional Trainers at Vocational Colleges in Malaysia
}

\author{
Abdul Sukor Nordin ${ }^{\text {a,1 }}$, Razali Hassan ${ }^{\text {a }}$, Azman Hasan ${ }^{\text {a }}$ \\ ${ }^{\mathrm{a}}$ Faculty of Technical and Vocational Education \\ Universiti Tun Hussein Onn Malaysia \\ Batu Pahat, Johor, MALAYSIA \\ ${ }^{1}$ sukor@iptho.edu.my
}

\begin{abstract}
Professional in teaching development is a main thrust in human development. It is vital to the teaching development of individuals, communities and nations. The purpose of this paper is to introduce Teaching of Professional Trainers at Vocational Colleges in Malaysia. The teaching professional will include critical components such as lesson planning and teaching which involve the teaching objectives, the nature of students, the viability of instructional objectives, teaching materials, lesson plans, the nature of teachers, learning outcomes and assessment. All these variables should be examined to produce a quality teaching of Professional Trainers at Vocational Colleges. This paper will discuss the models in teaching and the teaching criteria that should be complied as professional trainer.
\end{abstract}

Index Terms - teaching, professional development, technical trainers, vocational college.

\section{Introduction}

According to Simone [1] standard of teaching is a standard to measure the level of professionalism of the instructors in the Vocational College. Professional development as explained by Kate and Rob [2] is the development of trainers who can develop acknowledged teaching and learning. In the other hand, AbdulRahim [3] mentioned that the professional development of teachers is depending on teaching. Instructors in Vocational College defined as novice teachers and teachers who are currently servicing in the college. Vocational College was fully implemented in 2013 to replace the syllabus of Vocational Subjects in 2008 under the vocational education transformation plan implemented in 2011 by the Ministry of Education. Technical and Vocational Education Training (TVET) is an educational programs that implements the elements of technical and vocational education through 'handson' and providing jobs in the blue collar sector.

There are many teaching models in recent researches but Sim Model [4] is identified as important contribution as it emphasizes on teaching preparation, teaching knowledge, preparing lesson plans, preparation of teaching delivery and assessment approach to teaching objectives. Further more, Taba's Teaching Model [5], Gerlach and Ely's Model of Teaching (1961), Pierce and Lorber's Models of Teaching (1977) are other models that can be considered in teaching standard. Teaching is the key constructs in a professional teaching standards that required by the trainers in Vocational College.

\section{Objective and Methodology}

The objective of this paper is to discuss the models in teaching. By improving the quality of teaching, professional trainers can be produced effectively. The methodology used to accumulate the issues in this paper was through analysis and thorough reading from reports, papers, journals and articles by previous authors and researchers.

\section{Literature Review}

If we look through teaching professionalism by Mutha et al. in Murshid [6], teachers are better and more professional in the teaching and learning process of each teaching session. Basically, there are many tasks that must be carried out by a teacher in connection with profession as a teacher. Mutha et al. in Murshid [6] present three main kinds of tasks in teaching namely planning purposes, the materials and processes of effective teaching. According to Sabrina [7], a teacher should master the teaching material sand the ways of teaching as a basis for teaching and assessment competency.

According Wragg [8], teaching is an activity associated with the spread of knowledge and specific skills. It covers planning activity, management, delivery, guidance and assessment. It aims to disseminate knowledge ands kills to students effectively. According to Sabrina [7], the development of education brings a lot of changes in teaching activity. The style of teaching has under gone many changes and growing better. Teaching in the context may be interpreted as aprocess, communication, science and art.

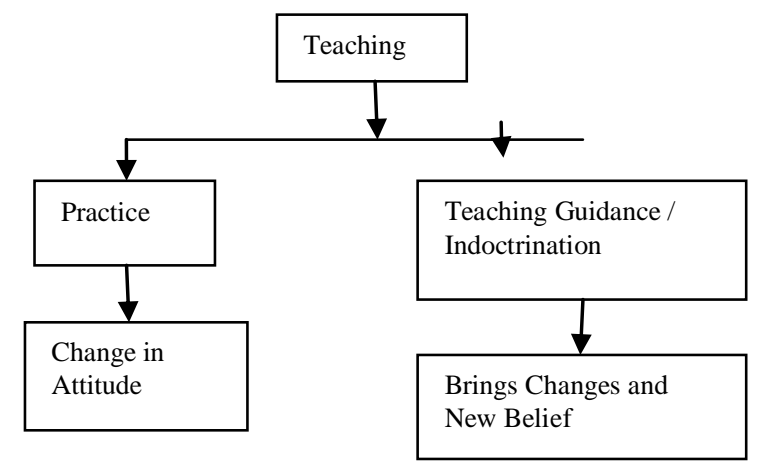

Fig. 1 Teaching Concept 
According to Razali (1997), the purpose of teaching is to change student behavior through the acquisition of knowledge. In the process of teaching and training activities, conditioning is an effort to change the behavior of the students, and guidance technic in doctrination can spread new knowledge and beliefs to students. To achievethe purpose of teaching according to Sim [4], the teaching process should be carried out systematically with appropriate steps such aspreparation of planning, implementation and evaluation of instructional delivery.

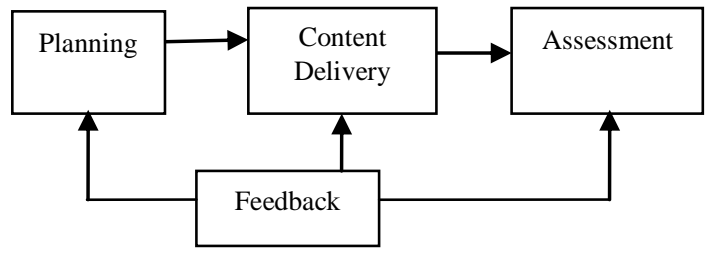

Fig. 2 Teaching Process

According to Morris \& Samuel [9], communication process involves teaching and interaction between teachers and students. Teaching should only happen if the lecturer can continue to communicate with the students in two ways. They can teach and the students could ask if they encounter learning problems. According to Ang [10], teaching is a series of scientific activity. Model of the teaching process is will determine student needs, define learning objectives, form learning activity, providing learning activities, learning and assess the objective achieved by the students. This is because an effective teaching only can happen with the use of principles and methods which have been reviewed and tested by the experts of educators. As for Taba [5], teaching plan emphasizes on the subject content, teaching strategies and teaching steps. Morris \& Samuel [9] states that all planning activity, management, delivery and assessment in the teaching process should be implemented systematically, based on principles, theories and teaching technic that was suggested by experts and educators. According to Sabrina [7], teaching contains characteristics of art which involves emotions, values and behavior of students. Teaching-learning theory is only useful if the theory could be applied to the students as a whole. This is because every individual has the potential of intellectual, emotional, spiritual and physical. To teach the diversity in students according to Morris \& Samuel [9], teachers must have a teaching talent, may customize models and theories of teaching and learning according to student's ability. Lesson objective may be achieved through the lecturer thatuse his talent for teaching design and delivery of teaching.

KPTM' steaching concept [11], teaching is a process of learning facilitation to help students develop their problemsolving skills and critical thinking. Sabrina [7] stated that teaching orientation focused on knowledge transmission. It is divided into three concepts namely :1) Learning is caused by the distinction between students; 2) learning is caused by teaching ; and 3) Learning is caused by the activity experienced by the students from their own efforts and the overall learning context. According to Huat (1999), the teaching approach must foster and consolidate students' interest in the lesson. Chosen teaching approachought to be interesting so that learning will become more meaningful, memorable and fun.

\section{Models of Teaching}

According to the Teaching Model Sim [4], effective teaching should have the objective that set by the instructor son students according to their ability. Lesson contents hould be selected based on the learning outcomes to be achieved. Teaching must have appropriate strategies for teaching to be more effective. A good relationship between teachers and students need to develop for effective teaching and learning environment. Teachers need to make an assessment of the lessons to ensure that the objectives are achieved. The learning environment is also important Sim [4] which includes perfect classrooms and labs, for the effectiveness of the teaching process.

Models of Teaching Robert Glaser [12], teaching process begins with the determination of appropriate teaching objectives. Teaching objectives describe what is to be acquired by students. Students should have prior knowledge in learning, so that the teachers can determine appropriate instructional objectives in implementing lesson plans. Appropriate teaching methods should be included in models of Teaching Robert Glaser [12],. Teaching method need to be adapted to students' prior knowledge and learning outcomes to be achieved. Every teaching process should be evaluated by the instructor based on the learning outcomes, existing knowledge and teaching methods. The results from this evaluation will provide feed back that allows the teacher to detect their weaknesses and strengths of teaching activities that have been implemented. This assessment allows teachers to enhance teaching methods to effective level.

Teaching Model Le Francois [13] is made up of three stages : pre-teaching, teaching and after teaching. For before teaching, instructors need to define the objectives. During the teaching, strategies of teaching should be defined and after teaching is to evaluate the effectiveness of teaching strategies. The quality of teaching according to Yong \& Karen [14] is to meet the teaching management, teaching strategies and evaluation of teaching. The quality of teaching also involves the preparation of teaching and learning in instructional planning, teaching knowledge, teaching delivery and evaluation teaching. Professional standards of teachers in Vocational College must meet the following matters, namely : (1) objectives of teaching; (2) the nature of students; (3) the viability of instructional objectives ; (4) instructional materials; (5) preparation of lesson plans; (6) the nature of teaching; and (7) learning outcomes and assessment.

According to Sim [4]: (1) teaching objective covers long term objectives and short-term objectives which include three areas of objectives which are cognitive objective, the field of affective objectives and objectives of students' psychomotor ; (2) The nature of the students should have existing experience in learning, the nature of the students, identify students in terms of their ability, achievement, interests and learning styles; (3) The viability of teaching is required to the students' level of ability; (4) teaching materials in which the instructor should consider the educational and teaching aids tool that can help teachers in 
effective teaching ;

(5) Preparation of lesson plans need to induction set and lesson content. The purpose of the induction set is to attract students to focus on the subject matter to be served. While the systematic learning content can ensure that it will be taught easily and effectively ; (6) The nature of teacher is in terms of teaching experience, teaching methods and teaching strategies are implemented; and (7) the learning assessment outcomes is from teaching the students. Through assessment activities, teachers can interpret the level of learning outcomes achieved.

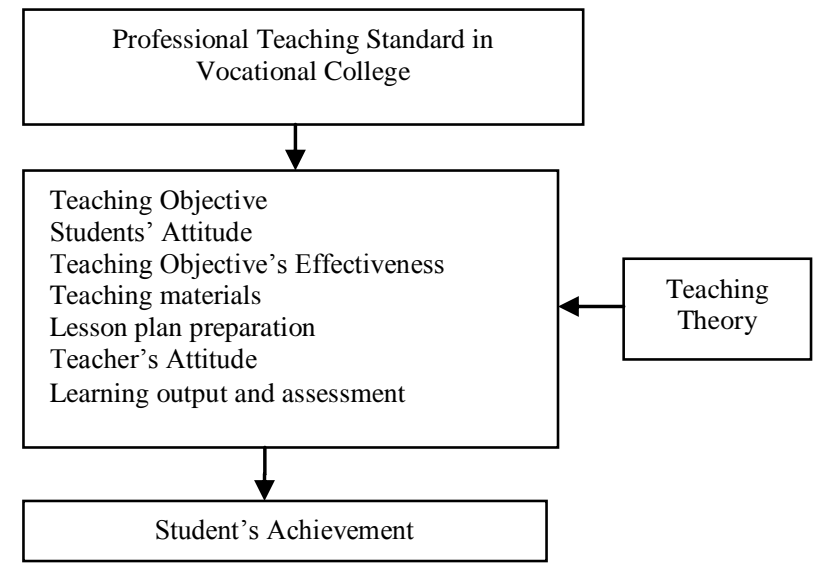

Fig. 3 Concept of Professional Teaching in VC (Adapted from Sim [4])

Professionalism Teaching Standard at Vocational College will result in the achievement of the students in Vocational College as anticipated. Teaching theory used is from Sim [4]. Sim's Teaching Model involves interactions between teachers and students, teachers and the objective of teaching, teachers with lesson content in the classroom and labs. According to Joanna \& Barry [15], school's environment and classroom is a place that needs to comfortable and satisfactory for learning. According to Joanna \& Barry [15], again determines that teacher's wisdom of setting the objectives and teaching content can determine the desired teaching outcome.

Professionalism of teaching according to Model Sim [4]consists of teaching knowledge and teaching plans. Teaching knowledge consists of substantive knowledge, syntactic knowledge, beliefs about the subject, curriculum knowledge, knowledge of the context, knowledge of himself, knowledge of teaching model, cognitive knowledge, empirical knowledge of students, knowledge of educational goal sand pedagogical knowledge. While the lesson plan consists of learning objectives, the nature of students, the viability of objectives, teaching materials, lesson plans, the nature of teachers, the teaching and assessment of learning.

\section{Discussion}

Based on Teaching Model by Sim [4], a professional teaching should have the following characteristics :(1) Objectives and teaching should be determined according to student's ability ; (2) The content should be based on learning outcomes and systematically planned in a suitable manner. Teaching materials should be appropriate to the interests and abilities of the students ; (3) Instructors should use appropriate teaching methods and teaching strategies for effective teaching; (4) There is a need for good relationship between teachers and students in order to create an atmosphere of effective teaching; and (5) The school environment, classroom and workshop facilities should fulfill there quirements of creating an advanced teaching process. Here it is proposed that a professional trainer should have the following characteristics: (1) talent in teaching ; (2) perform tasks in an efficient and effective teaching; (3) requires effective teaching method; (4) involves the study of effective teaching; and (5) can run teaching process optimally.

\section{Conclusion}

This concept paper is believed to provide useful information to the Ministry of Education especially in Technical and Vocational Education Division to evaluate professional teaching standards at the Vocational Colleges in Malaysia. These findings will determine whether the course objectives can be achieved bythe Vocational College according to Transformation Plan. This concept paper also helps BPTV to improve the weaknesses and identify the strength of each dimension in all aspects such as teaching preparation in Vocational College, preparation method of delivery, teaching and the assessment. This is useful information to MOE in arranging the strategies for instructors in Vocational College during the implementation of teaching and learningprograms in the future. Information from this paper will assist the MOE to review and reorganize the aspects in teaching such as teacher training, curriculum and for the evaluation of teaching performance. Quality teaching is so important in the development of a professional instructor. Trainers, departments and institutions need provide the best practice and implementation of professional trainer.

\section{References}

[1] Simone R. Kirpal (2011). National Pathways and European Dimensions of Trainers' Professional Development. Peter Lang. Frankfurt.

[2] Kate Jacques \& Rob Hyland ( 2005). Professional Studies Primary Phase. Bell \& Bain Ltd. Glasgow UK.

[3] Abd. Rahim Abd. Rashid (2005). Profesionalisme keguruan Prospek dan Cabaran. Dewan Bahasa Dan Pustaka. Kuala Lumpur.

[4] Sim, W.K., (1970). Satu Model Pedagogi Untuk Pengajaian Dalam Pengajaran Mikro. Masalah Pendidikan. Vol.2, No. 2. -1971 FEATS. Jurnal Pendidikan.

[5] Taba, H. (1971). Curriculum Development, Theory and Practice. New York : Brace and World.

[6] Mutha Hutajulu Tilhang Naibaho Lisbeth Siagian Lavanter J. Simamora Dosen dalam Dr. Murshid (2012). Program Studi Teknologi Pendidikan Program Pasca Sarjana Universita. Negeri Medan.

[7] Sabrina Laine (2011). Improving Teacher Quality. Jossey-bass A Wiley Imprint. United States of America.

[8] E. C. Wragg (1993). Classroom Teaching Skills.Biddles Ltd. Great Britain.

[9] Morris L. Bigge \& Samuel S. Shermis (2004). Learning Theories for Teachers. Pearson Education Inc. United States of America.

[10] Ang Huat Bin (1999). Konsep Dan Kaedah Pengajaran Dengan Penekanan Pendidikan Inklusif. Utusan Publication \& Distributors Sdn Bhd. Kuala Lumpur. 
[11] KPTM(2006). Modul Kursus Asas Pengajaran Dan Pembelajaran. Penerbit Univeersiti UPENA. Shah Alam.

[12] Robert Glaser (1992). Model Pengajaran.

[13] Le Francois (1992). Model Pengajaran.

[14] Yong, M.S. \& Karen, L. B. (1996). Guru Yang Kreatif. Arena Buku. Kuala Lumpur.

[15] Joanna Burchert\& Barry Nyhan (2012). Trainers' Conceptions of apprenticeship Training in Ireland and Germany. page 81-87 : Vocational Eduacation and Training. Band 8. 